\title{
ARBITRATION AND MEDIATION METHOD APPLIED TO ISLAMIC FINANCE CONFLICTS IN MALAYSIA
}

Nur Khalidah Dahlan, Mohd Rizal Palil, Noor Inayah Yaa'kub, Mohamad Abdul Hamid Institute of Malaysian and International Studies (IKMAS), Universiti Kebangsaan Malaysia, 43600 Bangi, Selangor, Malaysia

nkhalidahd@gmail.com

Faculty of Economics and Management, University Kebangsaan Malaysia, 43600 Bangi, Selangor, Malaysia mr_palil@ukm.my

Universiti Islam Malaysia, Blok I, Bangunan MKN Embassy Techzone, Jalan Teknokrat 2, 63000 Cyberjaya, Selangor, Malaysia noorinayah@uim.edu.my \& mohamad@uim.edu.my

\begin{abstract}
Malaysia has already known as an Islamic country. In a country of multi-ethnicity, multi-religion and multi-cultural societies, demands a concept of justice and equality that is different from other countries, particularly the ones with homogenous societies. The highest law of the land places Islam, the religion associated with one of the main ethnicity, as the official religion of the nation and allowed the duality of economic system, in particular banking system, whereby conventional banking system exists side-by-side with the Sharia-compliant, Islamic banking. By reviewing the pertinent literature on the development of Islamic banking, the reviewed cases on Islamic banking and its contributions to Malaysian society regardless of ethnicity and religion. The discussion in this paper therefore will be directed towards highlighting the laws and mechanisms of solution on Islamic banking and its implication to enhance the application of Islamic banking laws to consumers regardless of ethnicity and religion, in order to maintaining fairness and justice in a multi-ethnic society
\end{abstract}

\section{Indexing terms/Keywords}

Arbitration, Mediation, Sharia Advisory Council, Multi-ethnicity, Justice, Malaysia.

\section{Academic Discipline And Sub-Disciplines}

Alternative Dispute Resolution, Islamic Finance, Law

\section{Council for Innovative Research}

Peer Review Research Publishing System

\section{Journal: Journal of Social Sciences Research}

Vol. 6, No. 3

Jssreditor.cir@gmail.com

www.jssronline.com 


\section{INTRODUCTION}

In a multi-ethnic, multi-religion and multi-cultural country like Malaysia, there bound to have multiple problem occurs within the society. An effective dispute resolution mechanisms are needed to avoid any imbalance or disadvantages, be they social or economic, to any particular ethnicity or religion. Law that is enacted by the Legislative is therefore posited as one of the main mechanisms which is able to satisfy those needs and creates harmonious relation among various ethnics across the nation. In light of this, this paper seeks to review pertinent literature with the view of highlighting the principles of justice and just practices in Islamic banking activities that are fair to all Islamic banking consumers regardless of ethnicity or religion.

The discussion in this paper is divided into four sections. Section 2 is dedicated to describing the evolution on civil law and Sharia law in dealing with Islamic banking transactions. Section 3 is describing the alternative solutions (Arbitration \& Mediation) for Islamic Finance disputes and the conclusion for this paper will be in the last section.

\section{THE EVOLUTION ON CIVIL LAW AND ISLAMIC LAW IN DEALING WITH ISLAMIC BANKING TRANSACTIONS IN MALAYSIA}

According to Al-Ghazali (1937), Islamic banking institution is a financial institution that operates with the objective of carrying out transactions based on Islamic principles. The definition of Islamic banking institution however varies across countries and organizations. According to the Organisation of the Islamic Conference (OIC), Islamic banking institution is the financial institution that conducts its banking operations in accordance with Sharia principles and that bans the receipt of interest in any event. Based on section 2 of the Islamic Banking Act 1983, Islamic banking business is a banking business whose aims and operations do not involve any element which is not approved by the Religion of Islam. While according to section 2 of the Islamic Financial Services Act 2013, the term of "Islamic banking business" means the business of accepting Islamic deposits on current account, deposit account, savings account or other similar accounts, with or without the business of paying or collecting cheques drawn by or paid in by customers; or accepting money under an investment account; and provision of finance; and such other business.

The practice of Islamic banking is based on Sharia principles. Sharia Principles refer to the principles laid down in the Quran (Surah An-Nisa 4). Interpretation of Sharia gives rise to what is known as the principles of Flqh, which is an understanding of the principles of Islamic jurisprudence in general. Technically, Fiqh means practical knowledge of the Sharia position on a particular issue. However, Sharia principles are much broader than the principles of Fiqh. Sharia principles cover aqad, ibadat, akhlak (moral) and muamalat whereas the principles of Fiqh covers only matters of ibadat and muamalat. Sharia principles are considered as written legislations while principles of fiqh are derived from an understanding of the principles of Sharia law and are made by expert jurists (Ahmad Hassan, 1994).

Islamic banking is built on the principle which bans the acceptance of interest (riba'). It reflects the concept of fairness manifested through the concept of profit and loss sharing and banning of the practice of riba'. According to Obaidullah (2005), in the Islamic financial system, all transactions will be applied based on the norms of Islamic ethics as implemented in Sharia law. In essence, the foundation of the Islamic financial system can be described as "fair" and in accordance with Sharia law. The Islamic financial system allows the freedom to make such transactions. However, this does not mean that such transactions will be accepting the concept of Riba and Gharar in their transactions. All the transactions will still controlled and supervised by any practitioner according to the practice of Islamic Financial system.

Over the period from 1986 to 2012, currently there are 29 reported court cases that emphasize the concept of fairness over and over again, i.e. business or commercial activity must be fair and equitable ${ }^{1}$. In the case of Dato Hj. Nik Mahmud Daud v BIMB the plaintiff (Dato Hj. Nik Mahmud) obtained an Islamic financing under a Bai Bithamin Ajil (BBA) scheme from BIMB to finance his purchase of a house. The financing required him to execute two contemporaneous agreements with BIMB; one was for the BIMB to purchase the house from him

\footnotetext{
${ }^{1}$ Tengku Mariam Bt Tengku Sri Wa Raja \& Anor V Commisioner Of Religious Affair Terengganu, Tinta Press V Bank Islam Malaysia Berhad, Bank Islam Msia Berhad V Adnan Omar, Dato Hj Nik Mahmud Daud V Bimb, Bank Kerjasama Rakyat Msia V Emcee Corps Sdn Bhd, Shamil Bank Of Bahrain Ec (Islamic Bankers) V Bexico Pharmaceuticals Ltd \& Anor, Tahan Steel Corp Sdn Bhd V Bimb, Bank Islam Malaysia Berhad V Pasar Raya Peladang, Arab Merchant Bank Berhad V Silver Concept Sdn Bhd, Affin Bank V Zulkifli Abdullah, Malayan Banking Bhd V Marilyn Ho Siok Lin, Malayan Banking Bhd V Ya'kup Oje \& Anor, Bank Muamalat Malaysia Berhad V Suhaimi Bin Md Hashim, Latifah Bt Mat Zin V Rosmawati Bte Sharibun \& Anor, Bank Kerjasama Rakyat Malaysia Bhd V Psc Naval Dockyard Sdn Bhd, Arab Malaysian Finance Bhd V Taman Ihsan Jaya Sdn Bhd \& Ors (Koperasi Seri Kota Bukit Cheraka Bhd, 3rd Party), Light Style Sdn Bhd V Kfh ljarah House (M) Sdn Bhd, Bank Islam Malaysia Bhd V Lim Kok Hoe \& Anor, Bank Kerjasama Rakyat Malaysia Bhd V Sea Oil Mill Sdn Bhd \& Anor, Arab Malaysian Merchant Bank Bhd V Silver Concept Sdn Bhd, Bank Islam Malaysia Bhd V Azhar Bin Osman \& Other Cases, Mohd Alias Bi Ibrahim V Rhb Bank Bhd \& Anor, Tahan Steel Corp Sdn Bhd V Bimb, Kopeks Holdings Sdn Bhd V Bank Islam Malaysia Bhd, Bank Islam Msia Berhad V Mustaffar @ Mustaffa Bin Yacob \& Anor, Bank Islam Malaysia Bhd V Rhea Zadani Corp Sdn Bhd DIl, Cimb Islamic Bank Bhd V Lcl Corp Bhd \& Anor, Bank Muamalat Malaysia Bhd V Kong Sun Enterprise Sdn Bhd \& Yang Lain, Tan Sri Abdul Khalid Bin Ibrahim V Bank Islam Malaysia Bhd.
} 
for RM520,000, and another was for the BIMB to immediately resell the house to him for RM629,200. Sometimes later, the plaintiff defaulted on the monthly instalments, prompting BIMB to refer the case to the civil court in order to recover the loan. The court questioned the fairness of the BBA scheme and, in the end, passed the judgment in favour of the plaintiff.

Meanwhile in Bank Islam Malaysia Berhad v Pasaraya Peladang Sdn. Bhd. , the court allowed the bank's application which also involved a Bai Bithamin Ajil scheme. Again, a Bai Bithamin Ajil transaction involves two separate agreements and one security document. In the first agreement, the bank would purchase the property concerned from the chargor (the purchaser of the property who charges the property to the bank as collateral). In the second agreement, the bank would sell the property back to the chargor. Lastly, a security document that is a legal charge given by the chargor to the bank to enable the bank to sell the property in the event of default by the chargor. The chargor's defence that the transaction should be nulled due to the existence of an element of fraud was rejected by the court - the rational being that, based on the principle of Sharia law, all transactions that have been agreed and signed by all the parties to the agreement will be deemed to be understood by the parties, and that the parties have accepted the agreement voluntarily. Therefore, it cannot be said by any party to the agreement that there is an element of fraud in this Sharia-oriented agreement.

According to Abdul Ghafar Ismail (2011), contracts which are based on the principles of Sharia can be divided into three categories namely commercial contracts, participatory contract and support contract. Commercial contract is a contract of sale and purchase or exchange involving profit such as murabahah contract, Bai Bithamin Ajil, salam, istisna, and hire agreement contract such as ljarah. Participatory contract is a contract that involves capital investment to create a profitsharing relationship such as musyarakah, and mudharabah. The last category, the support contract, is a contract to fund and facilitate trade coupled with profit-sharing such as rahn, kafala, wadiah and ibraa.

In the case of Bank Islam Malaysia Bhd $v$ Rhea Zadani Corp Sdn Bhd, the bank (the plaintiff) had approved several Istisna facilities for the first defendant. The facilities were to finance the cost of the building a housing/shophouses project. In order to enforce the facilities, the bank executed the Istisna' purchase agreement and the Istisna' sale agreement. The defendants later defaulted and, in litigation argued, among others, that the two Istisna' agreements were not based on the true Istisna' principles. In passing the judgment in favour of the bank, the High Court Judge remarked that " the defendants' contention that the Istisna' agreements was not valid in Sharia without adducing any strong grounds in Sharia, was a lawyer's construct defence which was purported to merely discharge the defendants' obligations under the agreements and ought to be dismissed".

Again, in CIMB Islamic Bank Bhd v Lcl Corp Bhd \& Anor which involves BBA, bai-al-inah, a letter of 'hibah' and a payment of ta'widh, attempt to disqualify the Islamic financing on technical ground failed. The High Court Judge concluded that, "The parties had agreed to be bound to give effect to the ultimate intention of refinancing the first BBA facility........., that the nature of transaction embarked into by the parties was called al-inah or bai-al-inah, which the Sharia Advisory Council of Bank Negara Malaysia had officially endorsed in their legal rulings and resolutions.........that the relationship between the plaintiff and the first defendant was regulated by the terms and conditions they had agreed upon in their letter of offer and the assets purchase and asset sale agreements......., and that the plaintiff had the right to impose compensation (ta'widh) on overdue instalments and payments of the selling price as agreed".

The case of Bank Muamalat Malaysia Bhd v Kong Sun Enterprise Sdn Bhd \& Anor involves a financing under Al-Istisna scheme which was later restructured to Al-ljarah scheme. Here too the court rejected the customer's contention that the Al-ljarah scheme was unlawful, against the conventional banking practice, not in line with the National Land Code, against the Contracts Act as well as not a true Al-ljarah scheme

Finally, in Tan Sri Abdul Khalid Bin Ibrahim v Bank Islam Malaysia Bhd, attempt at High Court and Appeal Court to declare the BBA scheme as against Sharia principles was referred to section 56 and 57 of the Central Bank of Malaysia Act 2009. Section 56 authorizes the Sharia Advisory Council of Bank Negara Malaysia (SAC) to decide on matters regarding Sharia issues, while Section 57 makes the SAC's ruling binding on the civil courts. In allowing the appeal for the bank, the Appeal Court held that SAC's ruling on the case would not contravene the Federal Constitution, since SAC was appointed under a federal law passed by the Parliament.

All the above cases had raised two general issues namely whether financial products offered by Islamic banking institutions are Sharia compliant and whether the terms and conditions of the contracts embodied in such products are fair to all the parties involved.

In order to obtain unbiased opinions as to the most appropriate principles of Sharia to be applied in a particular case, a new independent body had been created and it is called Sharia Advisory Council (SAC). SAC's function as an expert reference body for Sharia matters concerning Islamic banking (Section 56 of Central Bank Act 2009). Any SAC's ruling will serve as a reference for the court or arbitrator trying or arbitrating Islamic banking cases. As stated in section 57 of Central Bank Act 2009, any ruling made by the SAC shall be binding on the Islamic Financials and its function is to ensure that the bank's business does not involve any element which is not approved by the religion of Islam. Nonetheless, if there are conflicting views, the position of precedence in the advice/ruling given is not clear. In practice, however, the ruling of SAC on any matter referred to it is not binding on the referring forum. In the case of Mohd Alias bin Ibrahim v RHB Bank Bhd \& Anor, the court held that the ruling of Sharia Advisory Council (SAC) was not binding on it. This shows that even though SAC is an expert opinion body in respect of Islamic finance matters, it will then be up to the courts to apply the ascertained law to the facts of the case. The High Court came to the similar conclusion in Tan Sri Abdul Khalid bin lbrahim $v$ Bank Islam Malaysia Bhd whereby it was held that it was upon the court to decide the matter before it and not the SAC. However, the High court did acknowledge the power of SAC to resolve all Sharia issues in Islamic banking 
SAC's extensive authority on Islamic banking is given under the Central Bank Act 2009. Section 58 of the act provides that where the ruling given by a Sharia body or committee constituted in Malaysia by an Islamic financial institution is different from the ruling given by the SAC, the ruling of the SAC shall prevail. In essence, section 58 creates no opportunity for different Sharia bodies/committees to issue conflicting ruling/advice on Islamic banking practice in Malaysia. Consequently, banks' customers, Muslims or non-Muslims, are equally subject to the same interpretation of Sharia principles on Islamic banking practice.

The diversity of the Islamic banking products that are based on the principles of Sharia has attracted interest of banking consumers, Muslims and non-Muslims alike, which resulted in increase in demand for such products. One of the attractive factors of Islamic banking products that brought about this surge in demand is that because Islamic financial products have no elements of riba (usury) and gharar (uncertainty). Further, they are also confined to lawful activities, perceived as fair and must of all it is in accordance with Islamic teachings (which is a selling factor for Muslim consumers).

Thus the role of SAC is very important in ensuring a fair and just Islamic banking practice in our multi-ethnic society. Apart from SAC, provides decisions on Sharia issues affecting Islamic banking and Takaful. Securities Commission (SC) too provides rulings on Sharia issues affecting Islamic capital market. In short, a combination of the jurisdiction of the Sharia Court, the laws and the roles of SAC is significant for achieving justice for all.

\section{INTRODUCTION ON ALTERNATIVE SOLUTIONS (ADR)}

There are other dispute resolution mechanisms available to the parties to resolve their disputes without going to court. Alternative Dispute Resolution (ADR) is a quick way to resolve the dispute, based on freedom of choice on the laws and procedures of their dispute.

Over 1,400 years ago, ADR methods have been used by Muslims to settle their differences amicably and this method has been encouraged by Islam and considered as a source of legislation. This is because Islam is a religion that emphasizes the concept of harmony instead of hostilities and embrace the principle of compromise rather than confrontation.

Justice without trial court was raised by Roscoe Pounds since 1912, he said that the court was crowded; delay in the trial is endemic; high costs; shortage of lawyers; overall substantive legislation that traditional legal and not current. Even Pound also said there is a difference in the usage and adoption of legislation among wealthy or poor. This is because the practice of law itself is often dominated by the rich for their favour. Clearly that the justice of the law does not guarantee equality of the overall concept (Pound, 1912).

Pound had put the two concepts of 'justice without law' and 'justice according to law'. As dissatisfaction with legal institutions increased in the early decades of the twentieth century, there was renewed interest in alternatives to litigation, particularly Conciliation and Arbitration (Pound, 1917 \& 1922). Both were touted as a quick, inexpensive procedure to waive counsel, the delay in the trial would result in an expensive cost to produce legal action.

'Alternative dispute resolution' or ADR is described as an alternative way other than through a court case to resolve the problems of the parties involved. Some examples of ADR done to solve the problem is the Arbitration (tahkim), conciliation, mediation, specialist expertise and Sulh.

\section{Arbitration}

According to Amin (1988), in pre-Islamic history, in Mecca the concept of tahkim (arbitration) has been known and practiced for solving various types of civil and commercial disputes. Arbitration decision (award) shall not be enforceable against the parties involved, unless the Chief of the tribe decided the arbitration decision is being enforced. However, the decision of the arbitrator appointed must be through confirmation of the parties involved. Typically, this process will be binding and binding on the parties concerned.

Some scholars have different views concerning the principles of arbitration. Hanafi and Shafi'i sect stated that the concept of arbitration is similar to the concept of peace. The decision decided through arbitration method will be binding on the parties involved but only when they agree. Yet, some of the followers of the Hanafi and Shafie argued that if an arbitral award is regarded as binding, this will challenge the government authorities, judges, and finally the authority of the chief (sultan). Meanwhile, for both Maliki and Hanafis', they believes that the decision rendered by an arbitrator will be binding unless it contains an element of unfairness. However, once the arbitration award filed in court, the judge, the decision will be binding and if the judge finds that no offense against the decision.

Reference to arbitration is an option to suit in court. Thus, if the case was not brought to the court, the parties concerned may agree to submit the case to the arbitrator to resolve. In Anson's Law of Contract is mentioned that:

It is not in dispute that the contract contains a clause that any dispute or disagreement among the parties shall be referred to and resolved by arbitration. Such clauses are valid and binding, but it cannot deprive the parties to take any legal questions to be determined by the ordinary courts.

Malaysian Arbitration Act 2005 (Act 646) was enacted on December 30, 2005 to bring fundamental reform of its arbitration rules. It is applicable to all commercial disputes including Islamic financial disputes where the parties agreed to refer to arbitration pursuant to an arbitration agreement signed by them. Chapter 3 (Section 12-17) describe the composition of an arbitrator pursuant to section 12 which provides that the parties are free to determine the number of arbitrators needed in those cases. 
Chapter 4 (Section 18-19) also provides for the jurisdiction of the arbitral tribunal, while Chapter 5 (Section 20-29) further provides the process of arbitration proceedings. Part III focus on the court has only some control over the arbitration proceedings. For example Section 21 provides freedom of the parties regarding the procedure to be followed by the arbitral tribunal when conducting the proceedings.

Section 36 also provides that a decision made by the arbitral tribunal pursuant to an arbitration agreement is final and legally binding on the parties involved. It can also be thought of as a defense, set-off or otherwise in any proceedings in any court and arbitral tribunal. Thus, the decision by the Arbitration Tribunal may not alter, amend, correct, revise, add to or cancel the award has been made. However, based on section 35, a decision made by the Arbitration Tribunal can be changed.

In addition, section 38, which states that the written application should be made to the High Court, and if the method of arbitration conducted in Malaysia or from overseas; section 39 will recognize a judgment as binding and enforceable through notes or through action.

Procedures in an arbitration generally the same as in the trial in civil court. Chapter 5 of the Arbitration Act, 2005 are describing the flow of an arbitration proceedings. The parties to the dispute will be treated with equality and each party will be given a fair and reasonable opportunity to present their case. The parties involved must agree to the procedure determined by the arbitral tribunal, if it does not agree, the tribunal may conduct the proceedings in such manner as it deems appropriate. The place of arbitration and the language used is independent and must be mutually agreed upon. The arbitral tribunal may appoint an expert to report to it on specific issues to be determined by the tribunal. If approved by the tribunal, the court can assist in taking evidence, the witness oath or affirmation before a high court officer or any other person, including the arbitral tribunal.

While the award made by panel of arbitrators is referring to section 31 Arbitration Act 2005, any decision of the arbitral tribunal shall be made by a majority panel of arbitrators and questions of procedure may be decided by the presiding arbitrator. Section 36 also explains that the decision of the arbitrator shall be final and binding. The parties involved may depend on the decision as a defence, set-off or otherwise in any proceedings in any court. The arbitral tribunal may not alter, amend, correct, revise, add to or cancel a decision made unless there is a request from the parties involved to correct or there are an additional award within 30 days of receipt of the decision.

Kuala Lumpur Regional Centre for Arbitration (KLRCA) is the centre where arbitration method is an option for those who seek alternative solution involving financial matters. KLRCA was established in 1978 by the Association of Asian-African Legal Consultative Organization (AALCO) to provide institutional support as a neutral and independent to conduct the arbitration in domestic and international markets. By virtue of an agreement between the Government of Malaysia and AALCO, the Malaysian Government to support the establishment of a regional centre for commercial arbitration in Kuala Lumpur and agreed to provide for the establishment of the centre. KLRCA capable with certain privileges and freedom to carry out its function as an international institution.

There are rules pertaining to Islamic finance matters when it comes to arbitration methods. Rules for KLRCA Arbitration (Islamic Banking and Financial Services) Act 2007 is associated with any commercial arbitration contracts, business or transaction based on Sharia principles. Therefore, any dispute arising out of any financial transaction which is subject to Sharia arbitration process shall be in accordance with the Regulations KLRCA (Islamic Banking and Financial Services) Act 2007.

Among the dispute that may adopt arbitration under the Rules KLRCA is as follows:

Any dispute, controversy or claim arising out of the business relating to Islamic finance, Islamic banking, takaful, Islamic capital market products or services or any other business transactions based on Sharia principles of this agreement / contract shall be decided by arbitration in accordance with the Rules of KLRCA (Islamic Banking and Financial Services).

\section{Mediation}

Meanwhile for mediation method, Islam explained that the practice of mediation methods (sulh) will be together practice with tahkim method. As prescribed in Surah An-Nisa (35)

And if you fear dissension between the two, send an arbitrator from his people and an arbitrator from her people. If they both desire reconciliation, Allah will cause it between them. Indeed, Allah is ever Knowing and Acquainted [with all things].

Mediation process are defined by Malaysian Mediation Centre (MMC) as "It's a voluntary process in which an impartial third party known as mediator, assists parties involved in a dispute to resolve their differences in an amicable manner."

In 1995, the Bar Council set up an Alternative Dispute Resolution Committee ('ADR Committee') to look into the possibility of setting up a mediation centre in Malaysia. The Bar Council launched its Malaysian Mediation Centre ('MMC') on 6 November 1999. The MMC encourages settlement of civil disputes. The MMC works under the auspices of the ADR Committee. The objectives of the MMC are to promote mediation as a means of alternative dispute resolution and to provide a proper avenue for successful dispute resolutions.

Malaysian statute for mediation method is referred to the Mediation Act 2012 which consists of seven parts. Part I is an interpretation and by referring to table 2 (a) of the Mediation Act 2012, its does not apply when related to the situation of the elections, criminal matters, any mediation performed by a judge, magistrate or officer of the court and carried out by the department of legal aid. Part II is preliminary matters for carrying out the method of mediation. Part III covers the appointment and termination of appointment Mediator. The next section (part IV) describes the procedures in mediation 
and Part V is the termination of the mediation rules. While Section VI describing the aspects of confidentiality and protection. Finally, in Part VII covers various aspects such as cost, power to amend the schedule, cost for mediator and its regulations.

Mediation methods programmed in MMC is an initiative of the applicant and scheduling as appropriate mediator. There are no legal implications liable towards the other party that does not attend the mediation proceedings. But for any contract that states the solution should be done in the method of mediation or arbitration in advance when there is a dispute, the refusal parties can be brought to legal action. However, the parties cannot take legal action for any breach of the contract.

Mediation methods usually related to business, organization, workplace disputes, community, planning and development issues. In most cases, mediation methods frequently is a form of commercial. According to Su'aida Safei (2008), the achievement of mediation methods are 155 cases were referred to the MMC since 2000 to August 2008 . 40 cases were completed, representing $28.38 \%$, while 18 cases were successfully representing $11.61 \%$. In 2008 , only 5 cases still pending, one case was not successful and 4 cases categorized as closed case.

\section{New Developments In Malaysia: Court Accompanying With Mediation Rules (Mediation)}

In 2011, Surianom Miskam and Nor 'Adha Abdul Hamid had mentioned in The Second Asian Business and Management Conference 2011 that the court accompanied by a method of mediation is a mediation program that uses judges as members of the mediator to help provide solutions to the parties involved. It is a service run by the judiciary as an alternative to trial. Kuala Lumpur Court Mediation Centre has been established to carry out a pilot project and then proceed to Kuala Lumpur and Klang, also were followed by other parts of the countries in Malaysia.

Court accompanied by mediation method has been incorporated into the process of the court to ensure that the method of mediation is also mandated as part of the process in civil litigation as it is available at no cost to the parties involved. According to Surianom Miskam and Nor 'Adha Abdul Hamid (2011), judiciary intended to send a strong message to litigants and lawyers that this process is under the jurisdiction of the court. Moreover, the mediation method will no longer be conducted in the judge's chambers, but done in the court. The Mediator will be appointed from panel judges of the High Court, Session Court and Magistrate's court.

When related to Islamic finance, the most important feature when there is a dispute and need an alternative solution is to refer to the Sharia Advisory Council of Bank Negara Malaysia. The law requires that an arbitrator of any disputes arising from Islamic financial business to refer to regulations prescribed by the Sharia Advisory Council or to seek advice from the Council to determine any issues relating to Sharia. Thus, justice for disputes in matters of Islamic finance would be more meaningful if the results of the justice system through fair process, within a reasonable time and expenses, and reflect the results in favour of both parties.

or other Roman font with serifs, as close as possible in appearance to Arial in which these guidelines have been set. The goal is to have a 9-point text, as you see here. Please use sans-serif or non-proportional fonts only for special purposes, such as distinguishing source code text. If Arial is not available, try the font named Computer Modern Roman. On a Macintosh, use the font named Times. Right margins should be justified, not ragged.

\section{CONCLUSION}

In summary, the function of law in a society is mainly to ensure the existence of adequate order; it provides resolutions to conflicts; it provides a safe haven for individuals and their assets, it maintains the structured operation of the civilisation; and it protects civil liberties as set forth in each nation's constitution. Admittedly, it is difficult to ascertain precisely whether a particular law, in its practical application, once legislated, will fulfil the requirements and the needs of the society. Nevertheless, where law is found to be unable to cope with the reality of the society, it must be amended so that it does not lose its relevancy in the society.

Law therefore must be kept current since it plays an important role in the society. The law lays down rules that govern private disputes, self-help actions or open-conflicts that may occur in the society. Here, courts, tribunals, arbitration and other dispute resolution forums are the main secular institutions in dispensing just resolutions in a society. As important as the court proceedings, ADR process is neutral, it is like a judge who served as the finder of fact and decision maker and provide the parties involved will merit evaluation of all aspects of the case. On Islamic banking regulation, SAC, being a subset of the banking law, does play a vital role in ensuring fairness and justice to the members of the Malaysian society.

Religion, however, also plays an important role in ensuring justice for all walks of life by lending its principles to the day-to-day affairs of the society. In order to take advantage of what religion has to offer, Malaysia has allowed the existence of a distinct Islamic banking system based on the precepts of Sharia law. In the context of Malaysia, the move to harmonize the jurisdiction of the civil legal system with the substantive and procedural aspects of Sharia law is an effort by the relevant authorities to bring the concept of unity and integration of the conventional and Islamic legal systems into practical reality. In a nutshell, we can conclude that harmonization of the two legal systems and, with the aid of SAC, do serve the purpose of fulfilling the demands of socio-legal reality i.e. adapting and bringing itself current with the changing surrounding. 


\section{REFERENCES}

[1] Hossain, Mohd Zakir. 2009. Why is Interest Prohibited in Islam? A Statistical Justification. Humanomics. Vol. 25 No. 4. 2009. pp. 241-253.

[2] Markom, Ruzian. Pitchay, Sharina Ali. Zainol, Zinatul Ashiqin. Abdul Rahim, Anita. Abdul Rahim Merican, Rooshida Merican. 2012. Adjudication of Islamic Banking and Financial Laws in the Civil Courts of Malaysia. European Journal Law and Economics. Springer.

[3] Obaidullah, M. 2005. Islamic Financial Services, Islamic Economics Research Center. King Abdul Aziz University. Jeddah.

[4] Pound, Roscoe. 1912. Social justice and legal justice, Mo. Bar Ass'n Proc. (1912), 110, 112; Reginald Heber Smith, Justice and the Poor (new York, 1919), 15.

[5] Pound, Roscoe. 1917. The limits of effective legal action, 3 American Bar Ass'n J. (Jan 1917), 55-57; Pound. 1922. An introduction to the philosophy of law (new haven, 1922), 54

[6] Shariff, Mohamed Ismail. 1998. The Development of Islamic Banking Law in Malaysia. (1998) 1 MLJ cxiv

[7] Syed Khalid Rashid. 2002. Factors Behind the Emergence of ADR in the World and ADR in Malaysia [2002] 1 LM at $p$ 70.

[8] Yilmaz, Ihsan. 2001. Law As Chameleon: The Question Of Incorporation Of Muslim Personel Law Into The English Law. Journal Of Muslim Minority Affairs. Vol. 21. No. 2.

[9] Yong Yung Choy. 2001. Alternative Dispute Resolution (Mediation) in Malaysia (December 2001), Insaf, 103 at p 107

[10] A.G. Guest. 1979. Anson's Law of Contract. Edisi 24, London: E.L.B.S. \& Oxford University Press.

[11] Mejelle. A Complete Code of Islamic Civil Law. Kuala Lumpur. The Other Press.

[12] Thani, Nik Norzrul. Abdullah, Mohamed Ridza. Hassan, Megat Hizaini. 2010. Law and Practice of Islamic Banking and Finance. 2nd Ed. Sweet \& Maxwell Asia.

[13] Khutubul Zaman bin Bukhari. 2003. Arbitration and Mediation in ASEAN: the Law \& Practice, in the 8th General Assembly 2003 at p 5 available at http://www.aseanlawassociation.org/ speechspubspub-malaysia.html

[14] Surianom Miskam, Nor 'Adha Abdul Hamid 2011, Alternative Dispute Resolution in Islamic Finance: From Adversarial to Non-Adversarial Justice, The Second Asian Business and Management Conference 2011, (pp. 224234), ISSN: 2186-5914, Proceedings URL: http://iafor.org/abmc_proceedings.html

[15] Tun Abdul Hamid Mohamad. 2011. Malaysian as an Islamic FinanceHub: Malaysian Law as the Law of Reference \& Malaysian Courts as the Forum for Settlement of Disputes. Presented in the 12th Conference of Prof. Emeritus Ahmad Ibrahim Memorial Lecture on 7 December 2011, Central Bank of Malaysia.

[16] The 14th Malaysian Law Conference held in the Kuala Lumpur Convention Centre (30 October 2007), Opportunities And Challenges In Islamic Commercial Law.

[17] Malaysian Federal Constitution

[18] Malaysian Islamic Bank Act 1983

[19] Malaysian Central Bank Act 2009

[20] Malaysian Banking and Finance Institutions Act 1989

[21] Malaysian Administration of Islamic Law (Federal Territories) Act 1993

[22] Malaysian Islamic Financial Services Act 2013

[23] Affin Bank v Zulkifli Abdullah, (2006) 3 MLJ 67

[24] Arab Malaysian Finance Bhd v Taman Ihsan Jaya Sdn Bhd \& Ors (Koperasi Seri Kota Bukit Cheraka Bhd, 3rd Party), (2008) 5 MLJ 631

[25] Arab Malaysian Merchant Bank Bhd v Silver Concept Sdn Bhd (2010) 3 MLJ 702,

[26] Bank Islam Malaysia Berhad v Adnan Omar (1994) 3 CLJ 735

[27] Bank Islam Malaysia Berhad v Pasaraya Peladang Sdn. Bhd. (2004) 7 MLJ 355

[28] Bank Islam Malaysia Bhd v Azhar Bin Osman \& Other Cases, (2010) 9 MLJ 192

[29] Bank Islam Malaysia Bhd v Lim Kok Hoe \& Anor, (2009) 6 MLJ 839

[30] Bank Islam Msia Berhad v Mustaffar @ Mustaffa Bin Yacob \& Anor, (2012) MLJU 668

[31] Bank Kerjasama Rakyat Malaysia Bhd v Psc Naval Dockyard Sdn Bhd, (2008) 1 CLJ

[32] Bank Kerjasama Rakyat Malaysia Bhd v Sea Oil Mill Sdn Bhd (2010) 2 MLJ 740,

[33] Bank Kerjasama Rakyat Msia v Emcee Corps Sdn Bhd, (2003) 1 CLJ 625

[34] Bank Muamalat Malaysia Berhad v Suhaimi Bin Md Hashim,

[35] Bank Muamalat Malaysia Bhd v Kong Sun Enterprise Sdn Bhd \& yang lain (2012) 6 CLJ, 
[36] Che Omar bin Che Soh v Public Prosecutor (1988) 2 MLJ 55 (SC) at p 56

[37] CIMB Islamic Bank Bhd v LCL Corp Bhd \& Anor (2012) 3 MLJ 869

[38] Dato Hj. Nik Mahmud Daud v BIMB (1998) 3 CLJ 605

[39] Dato' Kahar Shah bin Tun Sulaiman v datin Fauziah binti haron (2008) 7 MLJ 779(HC) at p 785 per Mohd Hishamudin J.

[40] Kamariah Bt Ali Dan Lain-Lain Lwn Kerajaan Negeri Kelantan, Malaysia Dan Satu Lagi (2002) 3 MLJ 657; (2002) 3 CLJ 766

[41] Kopeks Holdings Sdn Bhd V Bank Islam Malaysia Bhd, (2012) 4 MLJ 337

[42] Latifah Bte Mat Zin v Rosmawati Binti Sharibun, (2007) 5 MLJ 101

[43] Light Style Sdn Bhd v Kfh ljarah House (M) Sdn Bhd, (2009) 4 MLJ 575

[44] Malayan Banking Bhd v Marilyn Ho Siok Lin, (2006) 7 MLJ 249

[45] Malayan Banking Bhd v Ya'kup Oje \& Anor, (2007) 6 MLJ 389

[46] Mohd Alias bin Ibrahim v RHB Bank Bhd \& Anor (2011) 3 MLJ 26

[47] Sukma Dermawan Sasmitaat Madja v Ketua Pengarah Penjara Malaysia \& Anor (1999) 1 MLJ 286, (1999) 1 CLJ 481

[48] Tahan Steel Corp Sdn Bhd v Bimb, (2004) 6 CLJ 25

[49] Tan Sri Abdul Khalid Bin Ibrahim V Bank Islam Malaysia Bhd, (2012) 7 MLJ 597

[50] Tengku Mariam Bt Tengku Sri Wa Raja \& Anor v Commissioner Of Religious Affair Terengganu, (1969) 1 MLJ 110 $\mathrm{HC}$

[51] Tinta Press v Bank Islam Malaysia Berhad, (1987) 2 MLJ 192

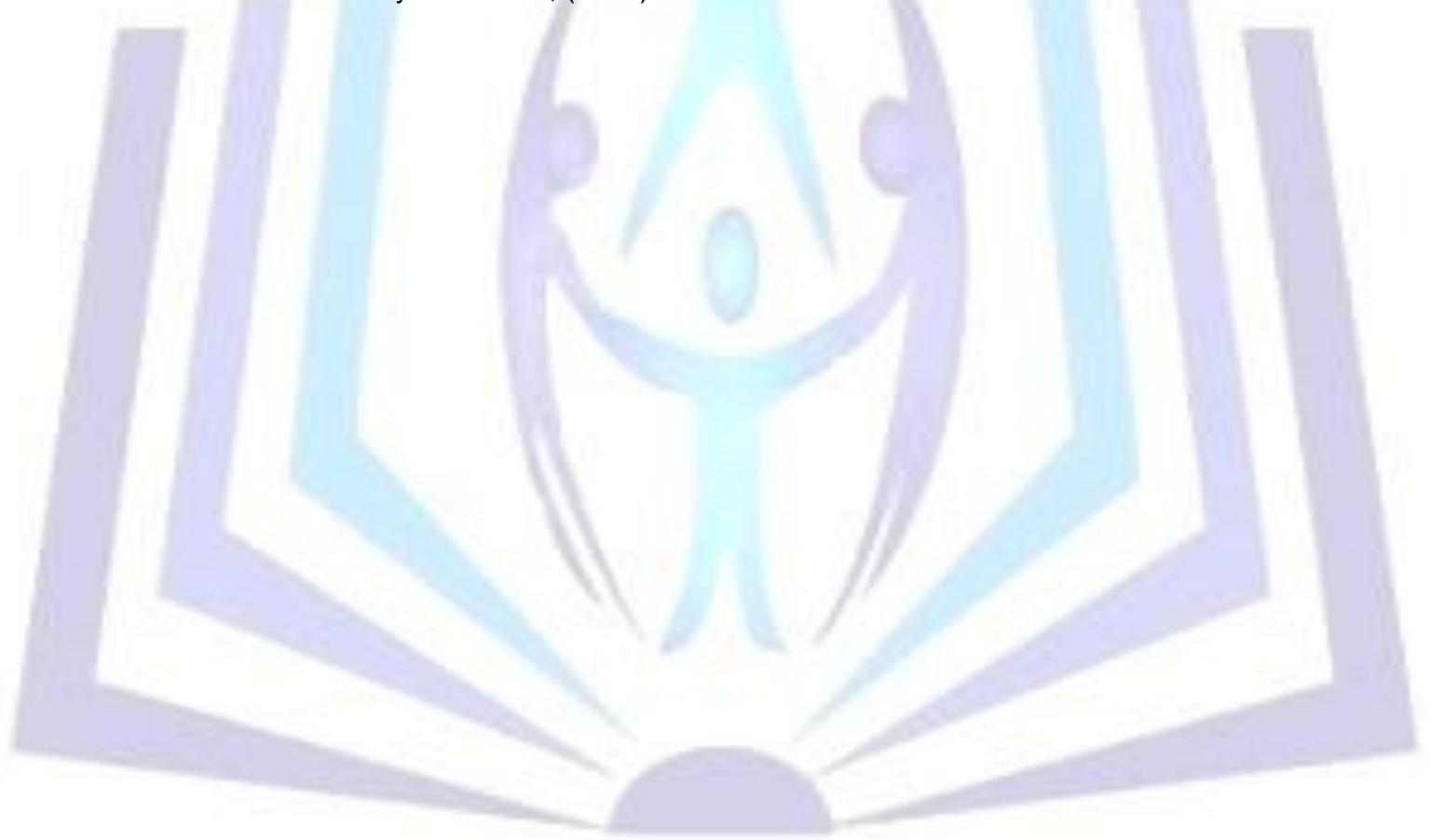

